\title{
CATALYTIC GASIFICATION OF COAL USING EUTECTIC SALT MIXTURES
}

\author{
Report for the period \\ April 1, 1998 to September 30, 1998 \\ Dr. Yaw D. Yeboah (PI) and Dr. Yong Xu (Co-PI) \\ Department of Engineering \\ Clark Atlanta University \\ Atlanta, Georgia 30314
}

\begin{abstract}
Dr. Atul Sheth (Co-PI)
The University of Tennessee Space Institute

411 B.H. Goethet Parkway

Tullahoma, TN 37388-8897
\end{abstract}

Dr. Pradeep Agrawal, Co-PI

School of Chemical Engineering

Georgia Institute of Technology

Atlanta, GA 30332

PREPARED FOR THE UNITED STATES DEPARTMENT OF ENERGY UNDER CONTRACT NUMBER DE-FG26-97FT97263 


\begin{abstract}
This progress report on the Department of Energy project DE-FG-97FT97263 entitled, Catalytic Gasification of Coal Using Eutectic Salt Mixtures, covers the period AprilSeptember 1998. The specific aims of the project for this period were to identify appropriate eutectic salt mixture catalysts for the gasification of Illinois \#6 coal, evaluate various impregnation or catalyst addition methods to improve catalyst dispersion, and evaluate gasification performance in a bench-scale fixed bed reactor. The project is being conducted jointly by Clark Atlanta University (CAU), the University of Tennessee Space Institute (UTSI) and the Georgia Institute of Technology (Georgia Tech) with CAU as the prime contractor.
\end{abstract}

Several single salt catalysts and binary and ternary eutectic catalysts were investigated at Clark Atlanta University. Physical mixing and incipient wetness methods were investigated as catalyst addition techniques. Gasification was carried out using TGA at CAU and UTSI and with a fixed-bed reactor at UTSI.

The results showed better gasification activity in the presence of the catalysts tested. The order of catalytic activity of eight single salt catalysts tested was:

\title{
$\mathrm{Li}_{2} \mathrm{CO}_{3}>\mathrm{Cs}_{2} \mathrm{CO}_{3}>\mathrm{CsNO}_{3}>\mathrm{KNO}_{3}>\mathrm{K}_{2} \mathrm{CO}_{3}>\mathrm{K}_{2} \mathrm{SO}_{4}>\mathrm{Na}_{2} \mathrm{CO}_{3}>\mathrm{CaSO}_{4}$
}

The eutectic salt studies showed clear agreement between the melting points of the prepared eutectics and reported literature values. The order of catalytic activity observed was ternary $>$ binary $>$ single salt. With the soluble single salt catalysts, the incipient wetness method was found to give better results than physical mixing technique. Also, catalyst preparation conditions such as catalyst loading, drying time and temperature were found to influence the gasification rate. Based on the Clark Atlanta University studies on Task 1, the project team selected the $43.5 \% \mathrm{Li}_{2} \mathrm{CO}_{3}-31.5 \% \mathrm{Na}_{2} \mathrm{CO}_{3}-25 \% \mathrm{~K}_{2} \mathrm{CO}_{3}$ ternary eutectic and the $29 \% \mathrm{Na}_{2} \mathrm{CO}_{3}-71 \% \mathrm{~K}_{2} \mathrm{CO}_{3}$ and $2.3 \% \mathrm{KNO}_{3}-97.7 \% \mathrm{~K}_{2} \mathrm{CO}_{3}$ binary eutectic for the fixed bed studies at UTSI.

The eutectic salts were found to be highly insoluble in aqueous medium. As a result the technique of adding the eutectic to the raw coal was found to be better than using wet methods. Also, addition of the catalyst to the raw coal appeared to give better gasification results than addition to pyrolyzed coal. In addition, eutectic catalysts added to the coal yielded better gasification rates than rates obtained by mixing the individual salts in the eutectic ratio with the coal. These results, especially with the eutectic catalysts are very significant since the use of the low melting eutectics will reduce the severity of gasification processes. 


\subsection{INTRODUCTION AND OBJECTIVES}

This progress report for the DOE grant DE-FG26-97FT97263 entitled, Catalytic Gasification of Coal Using Eutectic Salt Mixtures, covers the period April, 1998 to September, 1998. The overall objectives of the project are to identify appropriate eutectic salt mixture catalysts for coal gasification; evaluate various catalyst impregnation techniques to improve catalyst dispersion; evaluate effects of major process variables (such as temperature and system pressure) on coal gasification; evaluate the recovery, regeneration and recycle of the spent catalysts; and conduct thorough analysis and modeling of the gasification process to provide better understanding of the fundamental mechanisms and kinetics of the process. The project is conducted jointly by Clark Atlanta University (CAU), the University of Tennessee Space Institute (UTSI) and Georgia Institute of Technology (GT) with CAU as the prime contractor.

To meet the project objectives the proposed work has been subdivided into the following tasks.

Task 1 Selection of Eutectic Salt Mixtures: This task involves literature review; identification of appropriate eutectic salt mixtures; evaluation of catalyst application methods; characterization of the coal and catalyst samples; and TGA studies to evaluate gasification characteristics.

Task 2 Evaluation of gasification performance in a bench-scale, fixed-bed reactor: This task includes evaluation of catalyst dispersion; study of the effects of process variables on the performance of gasifiers; and evaluation of the recovery, regeneration and recycle of the catalysts.

Task 3 Data Analysis and Reporting: This encompasses data analysis and modeling; economic evaluation of the gasification process; and project management and reporting.

A summary of the progress and accomplishments on the project tasks are given in the subsequent sections.

\subsection{SUMMARY OF SIX MONTHS ACTIVITIES}

\subsection{Task 1: Selection of Eutectic Salt Mixtures}

This task is being executed at Clark Atlanta University. Details on the materials and experimental procedures used are given below.

\subsubsection{Materials}

Coal was prepared from ground Illinois \#6. Compositional data for the parent coal and for the char prepared from it are given in Table 1. The coal used in the lab is 60 mesh.

The salts investigated as catalysts and used for preparing the eutectic salts included Sigma Chemical Company analytical reagent grade $\mathrm{Li}_{2} \mathrm{CO}_{3}, \mathrm{Na}_{2} \mathrm{CO}_{3}, \mathrm{~K}_{2} \mathrm{CO}_{3}, \mathrm{LiOH}, \mathrm{KOH}$, $\mathrm{NaNO}_{3}, \mathrm{Cs}_{2} \mathrm{CO}_{3}, \mathrm{KNO}_{3}, \mathrm{LiNO}_{3}, \mathrm{~K}_{2} \mathrm{SO}_{4}$ and $\mathrm{CaSO}_{4}$. Gasification measurements were carried out in $\mathrm{CO}_{2}$ (Holox Products). 
Table 1. Compositional data for Illinois No.6 coal (hvCb rank)

\begin{tabular}{|c|c|c|c|}
\hline \multicolumn{2}{|c|}{ Proximate analysis (wt\%) } & \multicolumn{2}{c|}{ Ultimate analysis (wt\%) } \\
\hline $\mathrm{H}_{2} \mathrm{O}$ & 13.20 & Ash & 11.62 \\
\hline Ash & 11.62 & $\mathrm{C}$ & 57.33 \\
\hline Volatiles & 35.44 & $\mathrm{H}$ & 3.98 \\
\hline Fixed C & 39.74 & $\mathrm{~N}$ & 0.99 \\
\hline & & $\mathrm{S}$ & 4.80 \\
\hline & & $\mathrm{O}$ & 8.07 \\
\hline
\end{tabular}

\subsubsection{Procedure}

The catalyst and coal sample preparation methods, gasification by TGA, and zeta potential measurements followed at Clark Atlanta University are described below.

\section{A Preparation of eutectic catalysts}

Binary and ternary eutectic catalysts were prepared by fusion of finely ground salt mixtures having compositions corresponding to the eutectic melting temperatures, as obtained from published phase diagrams (1). Fusion was carried in air at temperatures at least $100{ }^{0} \mathrm{C}$ above the respective eutectic melting points. After cooling, the solidified melts were crushed and finely ground in an agate mortar. The melting points of the prepared eutectic catalysts were measured by Seiko Instruments DSC220C.

\section{B Preparation of samples(coal + catalyst)}

\section{B-1 Physical mixing technique}

Salt mixtures or eutectic catalysts were finely ground in an agate mortar and weighed amounts were then intimately mixed with the powdered coal in a Fisher Minimill to give an initial catalyst concentration of $10 \mathrm{wt} \%$ of each catalyst.

\section{B-2 Incipient wetness method}

Weighed powdered salt mixtures were dissolved in water. The solution was then added to the powdered coal and shaken to make sure the solution mixed well with the coal. The sample was subsequently dried in air for three days. Based on preliminary studies on the amount of water absorbed or needed to completely cover a given amount of coal, the ratio of water to coal was kept at $0.62 \mathrm{ml}$ of water/ gram of coal in the experiments.

\section{Gasification Test by TGA}

In order to compare the relative catalytic effects of the different catalysts in the gasification of coal with carbon dioxide, mixtures of powdered coal with $10 \mathrm{wt} \%$ of the different catalysts were prepared by two methods and the rate of weight loss of the samples when heated in a flowing gas of $\mathrm{CO}_{2}$ were measured at a series of constant temperatures. The catalyst samples studied are summarized in Tables 2, 3 and 4.

Measurements of gasification kinetics in flowing $\mathrm{CO}_{2}$ [140 ml/min at 1 atm $\left.(0.1 \mathrm{MPa})\right]$ were performed in a SDT 2960 Simultaneous DTA-TGA. Simultaneous thermal gravimetry-differential thermal analyses (TG-DTA) were performed at a linearly increasing temperature rate of $\mathrm{dT} / \mathrm{dt}=10{ }^{\circ} \mathrm{C} / \mathrm{min}$ in an atmosphere of flowing carbon dioxide gas. 
The balance was usually operated in the isothermal mode with weight changes being recorded as a function of time at a series of TGA settings in the range $550-1000{ }^{\circ} \mathrm{C}$. At each temperature, gasification was continued for $\sim 10 \mathrm{~min}$ to assure that steady state conditions were attained. The gasification rate at each temperature and time were derived from the relation:

rate $\left(\mathrm{min}^{-1}\right)=-(\delta \mathrm{W} / \delta \mathrm{t})(1 / \mathrm{W})$

where $\mathrm{W}$ is the weight of the sample at time t.

Table 2. Single salts physically mixed with fresh coal

\begin{tabular}{|c|c|c|c|}
\hline & $\mathrm{CO}_{3}{ }^{2-}$ & $\mathrm{NO}_{3}{ }^{-}$ & $\mathrm{SO}_{4}{ }^{2-}$ \\
\hline $\mathrm{Li}^{+}$ & $\mathrm{y}$ & $\mathrm{y}$ & $\mathrm{y}$ \\
\hline $\mathrm{Na}^{+}$ & $\mathrm{y}$ & $\mathrm{y}$ & $\mathrm{n}$ \\
\hline $\mathrm{K}^{+}$ & $\mathrm{y}$ & $\mathrm{y}$ & $\mathrm{y}$ \\
\hline $\mathrm{Cs}^{+}$ & $\mathrm{y}$ & $\mathrm{y}$ & $\mathrm{n}$ \\
\hline $\mathrm{Ca}^{++}$ & $\mathrm{y}$ & $\mathrm{n}$ & $\mathrm{y}$ \\
\hline
\end{tabular}

y-sample tested. n-no sample tested.

Table 3. Single salt solutions mixed by incipient wetness method with fresh coal

\begin{tabular}{|c|c|c|c|}
\hline & $\mathrm{CO}_{3}{ }^{2-}$ & $\mathrm{NO}_{3}{ }^{-}$ & $\mathrm{SO}_{4}{ }^{2-}$ \\
\hline $\mathrm{Li}^{+}$ & $\mathrm{n}$ & $\mathrm{n}$ & $\mathrm{n}$ \\
\hline $\mathrm{Na}^{+}$ & $\mathrm{y}$ & $\mathrm{y}$ & $\mathrm{n}$ \\
\hline $\mathrm{K}^{+}$ & $\mathrm{y}$ & $\mathrm{y}$ & $\mathrm{y}$ \\
\hline $\mathrm{Cs}^{+}$ & $\mathrm{y}$ & $\mathrm{n}$ & $\mathrm{n}$ \\
\hline $\mathrm{Ca}^{++}$ & $\mathrm{n}$ & $\mathrm{n}$ & $\mathrm{n}$ \\
\hline
\end{tabular}

y-sample tested. n-no sample tested.

Table 4. Binary eutectic salt catalysts used in the carbon dioxide gasification of coal.

\begin{tabular}{|c|c|c|c|}
\hline & $\begin{array}{c}\text { solid salt mixing with } \\
\text { coal }\end{array}$ & $\begin{array}{c}\text { eutectic catalyst } \\
\text { mixing with coal }\end{array}$ & $\begin{array}{c}\text { salt solution } \\
\text { mixed with coal }\end{array}$ \\
\hline $43.2 \% \mathrm{Li}_{2} \mathrm{CO}_{3}-57 \% \mathrm{~K}_{2} \mathrm{CO}_{3}$ & $\mathrm{y}$ & $\mathrm{y}$ & $\mathrm{n}$ \\
\hline $62 \% \mathrm{Li}_{2} \mathrm{CO}_{3}-38 \% \mathrm{~K}_{2} \mathrm{CO}_{3}$ & $\mathrm{y}$ & $\mathrm{y}$ & $\mathrm{n}$ \\
\hline $2.3 \% \mathrm{~K}_{2} \mathrm{CO}_{3}-97.7 \% \mathrm{KNO}_{3}$ & $\mathrm{y}$ & $\mathrm{y}$ & $\mathrm{y}$ \\
\hline $2.2 \% \mathrm{Na}_{2} \mathrm{CO}_{3}-97.8 \% \mathrm{NaNO}_{3}$ & $\mathrm{y}$ & $\mathrm{n}$ & $\mathrm{n}$ \\
\hline $71 \% \mathrm{Na}_{2} \mathrm{CO}_{3}-29 \% \mathrm{~K}_{2} \mathrm{CO}_{3}$ & $\mathrm{y}$ & $\mathrm{y}$ & $\mathrm{y}$ \\
\hline $48 \% \mathrm{Li}_{2} \mathrm{CO}_{3}-52 \% \mathrm{Na}_{2} \mathrm{CO}_{3}$ & $\mathrm{y}$ & $\mathrm{n}$ & $\mathrm{n}$ \\
\hline $48 \% \mathrm{CaCO}_{3}-52 \% \mathrm{CaSO}_{4}$ & $\mathrm{y}$ & $\mathrm{y}$ & $\mathrm{n}$ \\
\hline $3.6 \% \mathrm{~K}_{2} \mathrm{CO}_{3}-96.4 \% \mathrm{KOH}$ & $\mathrm{y}$ & $\mathrm{n}$ & $\mathrm{y}$ \\
\hline $57 \% \mathrm{Li}_{2} \mathrm{CO}_{3}-43 \% \mathrm{CaCO}_{3}$ & $\mathrm{y}$ & $\mathrm{y}$ & $\mathrm{y}$ \\
\hline $8.3 \% \mathrm{Na}_{2} \mathrm{CO}_{3}-91.7 \% \mathrm{NaOH}$ & $\mathrm{y}$ & & \\
\hline
\end{tabular}




\section{Surface Charge Measurements}

A coal catalyst slurry was prepared in water and the $\mathrm{pH}$ of the slurry sample was measured using a Corning $\mathrm{pH}$ meter 430 . The surface charge on the sample was subsequently measured in aqueous solutions by a Pen Kem Model 501 Laser Zee Meter at CAU.

\subsection{Task 2: Evaluation of gasification performance in bench-scale fixed-bed reactor}

The high-pressure, high-temperature fixed-bed catalytic coal gasification experiments using eutectic salt mixtures are being carried out at the University of Tennessee Space Institute (UTSI) to initially choose a better catalyzed coal preparation technique and to optimize the process variables for an efficient gasification process.

\section{A Coal Preparation}

Several preparation steps are involved before coal is gasified. These include catalyst addition, drying and sieving, and devolatilization (pyrolysis).

\section{B Catalyst Addition Techniques}

The techniques that were used during the course of experimentation at UTSI are described below.

\section{B-1 Physical Mixing (M1)}

The alkali and alkaline earth metal salts were used as a catalyst mixture at its eutectic composition. This mixture was heated to about $100{ }^{\circ} \mathrm{C}$ above its melting point to form a eutectic. The resulting glassy material was then crushed and added to coal in required amounts.

\section{B-2 Wet Mixing of Eutectic Salts (M2)}

The eutectic mixture prepared by the above method was made into slurry (because it was insoluble in water) by adding sufficient amount of water to just wet the coal (i.e., incipient wetness method). For the Illinois No.6 coal, the amount of water required was around 2 $\mathrm{ml} / 5 \mathrm{gm}$ of dry coal. The thick paste was thoroughly mixed for good distribution of the catalyst and then dried in an oven at $\sim 110^{\circ} \mathrm{C}$.

\section{B-3 Wet Mixing of Individual Salts (M3)}

The alkali and alkaline earth metal salts were physically mixed following their eutectic composition, and the resulting mixture was dissolved in water. This solution was added to coal to sufficiently wet it. The thick paste was mixed thoroughly and then dried in an oven at $\sim 110{ }^{\circ} \mathrm{C}$.

\section{Drying}

The coal prepared by the wet techniques (M2 or M3) described above was dried in a Precision - Gravity Convection Oven at $110^{\circ} \mathrm{C}$ for 12 hours. The resulting dry coal was crushed in an agate mortar and subsequently used for pyrolysis in a tube furnace. 


\section{Devolatilization/Pyrolysis}

The devolatilization step was carried out separately from the gasification step to avoid the difficulties in handling the tars that come out during pyrolysis. The dry crushed coal with catalyst was filled in small sample boats, placed in the stainless steel reactor to be heated in the tubular furnace - Mellen Model TS-2200-231-3. Pyrolysis was carried out at $1350{ }^{\circ} \mathrm{F}$ for 3-4 hours under $\mathrm{N}_{2}$ atmosphere. The pyrolysed coal was cooled under inert conditions, crushed using agate mortar and sieved to collect the fraction between 30 mesh and 100 mesh. This fraction was used for gasification.

\section{E Gasification}

Steam gasification was carried out in a bench scale high-pressure, high temperature, fixedbed gasification unit. The operating conditions for Runs 1 to 4 (See Figure 1) were

Temperature $: 1350^{\circ} \mathrm{F}$

Pressure $\quad: 50 \mathrm{psig}$

Catalyst used : $\mathrm{LiCO}_{3}-\mathrm{Na}_{2} \mathrm{CO} 3-\mathrm{K}_{2} \mathrm{CO}_{3}$ (LNK) ternary eutectic-10 wt. \%

Steam flow rate: $0.2 \mathrm{ml} / \mathrm{min}$

Purge gas $\quad: \mathrm{N}_{2}$ (at $60 \mathrm{psig}$ )

Sample size $: 2.55$ grams of char

Gasification time: 240 min (arbitrarily chosen)

The initial experiments (Runs 1 to 4) were conducted to select a better technique of catalyst addition which would give desirable gasification rates.

\section{F Bench Scale High Pressure High Temperature Fixed - Bed Gasification Unit}

A SS-304 3/4 " diameter tube of $0.065 "$ wall thickness was used as a reactor with a working design pressure greater than 1500 psi at $1400{ }^{\circ} \mathrm{F}$. It was randomly packed with ceramics beads, above which coal was placed a stainless steel 200-mesh basket. A type-K thermocouple was used to measure the temperature of the bed. The reactor was heated using a long vertical furnace - SIB Lindberg Model 123. The water and inlet gases were preheated using a separate 4" long furnace - SIB Lindberg Model 123. The pressure was maintained in the reactor using a Tescom Industrial Controls Model 26-1726-24 backpressure regulator. The cooled gases passed through a Rockwell T-110 cumulative gas flowmeter to determine their total volume. The gas samples were analyzed in an SRC 8610C TCD gas chromatograph (GC). Water was pumped against a backpressure of 800 psi into the preheater using a Dionex Model DQP-1 pump. The char samples were analyzed for its fixed carbon content before and after the gasification in a thermogravimetric analyzer - Perkin Elmer TGA 7.

The data from the gas chromatograph was analyzed using the 'PeakSimple' software and the resulting concentrations of various gaseous species were used to obtain the gasification rates and extent of conversion for each run. 


\subsection{Study on TGA reproducibility}

Pyrolysis of raw Illinois No.6 coal in 1 atm nitrogen gas as a function of temperature conducted at $\mathrm{CAU}$ is shown in Figure 2. As the temperature increased from room temperature to $700{ }^{\circ} \mathrm{C}$, the water and the volatiles existing in the coal were mostly lost. The weight loss increased quickly at the initial temperatures and after $700{ }^{\circ} \mathrm{C}$, the rate of increase decreased slowly and the coal sample weight became more stable. The gasification results in $\mathrm{CO}_{2}$ of two char samples from the above pyrolysis studies are shown in Figure 3. The gasification rate increased with temperature. The results show excellent reproducibility.

\subsection{Evaluation of the eutectic catalysts and application methods}

The results of the CAU kinetic experiments with the samples from Tables 2 and 3 are shown in Figures 4-6. These results were obtained by the physical mixing technique. The gasification rates of the coal with catalysts were greater than that with the raw coal. The catalytic activities exhibited by the $\mathrm{Li}$ salts were greater than those of $\mathrm{Cs}, \mathrm{K}, \mathrm{Na}$, and $\mathrm{Ca}$ salt. The order of catalytic activity of eight single salt catalysts used was as follows:

\section{$\mathrm{Li}_{2} \mathrm{CO}_{3}>\mathrm{Cs}_{2} \mathrm{CO}_{3}>\mathrm{CsNO}_{3}>\mathrm{KNO}_{3}>\mathrm{K}_{2} \mathrm{CO}_{3}>\mathrm{K}_{2} \mathrm{SO}_{4}>\mathrm{Na}_{2} \mathrm{CO}_{3}>\mathrm{CaSO}_{4}$.}

For the single salt catalysts, the incipient wetness method yielded enhanced gasification rates as seen in Figures 7 and 8 compared to the results for the same composition samples prepared by physical mixing. The incipient wetness method probably increases the catalyst dispersion and offers more effective active sites, thereby resulting in a higher gasification rate. Characterization of the samples to determine the dispersion is currently being undertaken by the project team from Georgia Tech.

The melting points of some of the binary and ternary eutectic catalysts prepared and measured by DSC technique at CAU are summarized in Table 5. The results show that the melting points of the eutectic catalysts prepared at CAU match the reported reference data well (1). Unfortunately, the DSC instrument used in the lab could only measure melting points below $550{ }^{\circ} \mathrm{C}$. Thus, samples with melting points above $550{ }^{\circ} \mathrm{C}$ were not measured. Based on the differences between the measured melting points and the literature values for the samples for which data is available, however, we believe the melting points for those samples not determined will be close to their literature values.

With binary and ternary eutectic catalysts added to the coal, marked increases in gasification rates were observed (see Figures 9-13). It is evident that the eutectic catalysts were more active than the individual salt components. The low melting eutectics were found to be very active. It is very interesting to compare the differences in catalyst activity for the same composition samples prepared by different application methods. The results follow the same trend as those for the single salts. Thus, the incipient wetness method with binary salts dissolved in the eutectic ratio gave higher results than the physical mixing technique. It is possible that the physical state of the catalyst may 
influence the relative catalytic activity. The observed activity order of incipient wetness>physical mixing, may be ascribed to dispersion effects. The incipient wetness method allows the catalyst to penetrate into the pores of the coal sample and also enhances uniform distribution of the catalyst within the coal thereby increasing the dispersion, catalyst utilization and effectiveness. Figure 14 also shows that the eutectic activity increased on repeated cycling experiments after cooling, probably because the molten catalyst phase continued to spread over the coal substrate attaining a more effective dispersion. The results of the characterization studies at Georgia Tech will shed some light on these results and deductions.

Table 5. Eutectic catalyst compositions and melting points by DSC.

\begin{tabular}{|c|c|c|c|c|}
\hline No. & $\begin{array}{c}\text { Eutectic salt } \\
\text { composition } \\
(\mathrm{mol} \%)\end{array}$ & $\begin{array}{c}\text { Melting point (C) } \\
\text { from literature }\end{array}$ & $\begin{array}{c}\text { Melting point } \\
(\mathrm{C}) \\
\text { By DSC }\end{array}$ & $\begin{array}{c}\text { Heated } \\
\text { temperature } \\
(\mathrm{C})\end{array}$ \\
\hline 1 & $\begin{array}{c}43.5 \% \mathrm{Li}_{2} \mathrm{CO}_{3-} \\
31.5 \% \mathrm{Na}_{2} \mathrm{CO}_{3}-25 \% \mathrm{~K}_{2} \mathrm{CO}_{3}\end{array}$ & 400 & 391.8 & 525 \\
\hline 2 & $58 \% \mathrm{Na}_{2} \mathrm{CO}_{3}-42 \% \mathrm{Li}_{2} \mathrm{CO}_{3}$ & 514 & 485.1 & 640 \\
\hline 3 & $57.1 \% \mathrm{~K}_{2} \mathrm{CO}_{3}-42.9 \% \mathrm{Li}_{2} \mathrm{CO}_{3}$ & 499 & 485.1 & 625 \\
\hline 4 & $62 \% \mathrm{Li}_{2} \mathrm{CO}_{3}-38 \% \mathrm{~K}_{2} \mathrm{CO}_{3}$ & 488 & 479.0 & 610 \\
\hline 5 & $71 \% \mathrm{Na}_{2} \mathrm{CO}_{3}-29 \% \mathrm{~K}_{2} \mathrm{CO}_{3}$ & 143 & 121.0 & 300 \\
\hline 6 & $48 \% \mathrm{Na}_{2} \mathrm{CO}_{3}-52 \% \mathrm{Li}_{2} \mathrm{CO}_{3}$ & 485 & 483.5 & 610 \\
\hline 7 & $43.5 \% \mathrm{Li}_{2} \mathrm{CO}_{3-}$ & 400 & 394.9 & 525 \\
\hline
\end{tabular}

\subsection{Evaluation of the effect of preparation conditions on the catalytic activity}

Three different catalysts were used to study the effects of catalyst loading, drying temperature and drying time on the gasification of Illinois \#6 at CAU. As shown in Figure 15 significant differences were observed between the activities of $\mathrm{K}_{2} \mathrm{CO}_{3}, 29 \% \mathrm{Na}_{2} \mathrm{CO}_{3}$ $71 \% \mathrm{~K}_{2} \mathrm{CO}_{3}$ and $43.5 \% \mathrm{Li}_{2} \mathrm{CO}_{3}-31.5 \% \mathrm{Na}_{2} \mathrm{CO}_{3}-25 \% \mathrm{~K}_{2} \mathrm{CO}_{3}$ in $\mathrm{CO}_{2}$ gasification. With increasing catalyst loading, the gasification rate increased. The higher catalyst levels enhance the availability of more active sites for catalysis. The experimental results also show that the drying time and temperature affect the catalyst activity and hence gasification rate (see Figures $16 \& 17$ ). Adequate mixing time and drying temperature lead to more uniform distribution of the catalyst and enhances catalyst dispersion. From Figure 16, it appears drying at room temperature results in the best catalytic activity and gasification rate. Higher drying temperatures however enhance sintering of the catalyst leading to loss of active surface area and lower catalytic activity as seen in Figure 17.

\subsection{The surface electronic property}

The surface charge properties of the samples were studied at CAU and are shown in Figures $18 \& 19$. By changing the content of catalyst (amount and type), different $\mathrm{pH}$ solutions were obtained. As the $\mathrm{pH}$ of the sample increased, the zeta potential of the sample decreased (Figure 18). Also as the surface charge became more negative the 
gasification rate appeared to increase. The reasons and explanations for these observed interesting behavior are still unclear and are currently being investigated.

\subsection{Fixed Bed Gasification Results}

Based on the Clark Atlanta University results on Task 1, the project team recommended the use of the $43.5 \% \mathrm{Li}_{2} \mathrm{CO}_{3}-31.5 \% \mathrm{Na}_{2} \mathrm{CO}_{3}-25 \% \mathrm{~K}_{2} \mathrm{CO}_{3}$ (LNK) eutectic catalyst for the UTSI fixed-bed gasification experiments. The TGA results from the fixed bed gasification runs at UTSI were analyzed and the fixed carbon and ash content in each run are tabulated in Table 6. The experimental results were close to the calculated values of the percentages of the fixed carbon and ash in each feed to the fixed-bed (within $5 \%$ error). The extent of conversion in each run for a gasification time of $240 \mathrm{~min}$ are compared in Table 7. From the GC results and material balance calculations, the specific gasification rate ($1 / \mathrm{C})^{*}(\mathrm{dC} / \mathrm{dt})$ was calculated for each time interval and correlated with the respective carbon conversion (based on char content). The resulting plots of the specific gasification rate versus fractional carbon conversion are given in Figure 20.

Table 6. Fixed Carbon and Ash Analysis for Runs 1 to 4

\begin{tabular}{|c|c|c|c|c|}
\hline & \multicolumn{2}{|c|}{ Experimental (wt. \%) } & \multicolumn{2}{c|}{ Calculated (wt. \%) } \\
\hline Run & Fixed carbon & Ash & Fixed Carbon & Ash \\
\hline 1 & 72.7 & 27.3 & 74.3 & 25.7 \\
\hline 2 & 71.2 & 28.9 & 71.9 & 28.1 \\
\hline 3 & 63.1 & 36.9 & 69.8 & 30.2 \\
\hline 4 & 65.1 & 34.9 & 69.8 & 30.2 \\
\hline
\end{tabular}

Table 7. Comparison of Carbon Conversions for Runs 1 to 4

\begin{tabular}{|c|c|c|}
\hline Run & Xc (based on GC results) & Xc (based on TGA results) \\
\hline 1 & 41.4 & 58.97 \\
\hline 2 & 75.35 & 97.74 \\
\hline 3 & 94.6 & 99.9 \\
\hline 4 & 98.3 & 99.9 \\
\hline
\end{tabular}

The conversions based on TGA results were calculated using the formula below:

$\mathrm{Xc}=[(\mathrm{Co}-\mathrm{C}) / \mathrm{Co}]^{*} 100$

Co: Initial carbon content in the feed to gasifier $(\mathrm{g})$

$\mathrm{C}$ : Final carbon content after gasification $(\mathrm{g})$

The four runs that were carried out by different catalyst application techniques helped in selecting a better method to proceed with in our further investigation to evaluate the effect of other process variables. The process of adding the $43.5 \% \mathrm{Li}_{2} \mathrm{CO}_{3}-31.5 \% \mathrm{Na}_{2} \mathrm{CO}_{3}-$ $25 \% \mathrm{~K}_{2} \mathrm{CO}_{3}$ catalyst to the raw coal gave better gasification rates than its addition to pyrolyzed coal. Regarding finding a suitable way of adding the catalyst, it was found that catalyst added as a eutectic composite gave a better gasification rate than the rate obtained by adding the catalyst mix as individual salts in the eutectic ratio. It was observed that the 
eutectic formed was highly insoluble in water, which made gasification by physical mixing a little higher than by wet methods. The data that is presented graphically in Figure 20 is from the gas chromatograph results that are yet to be reconciled. The reconciliation would be based on the TGA and GC results to ensure carbon and hydrogen balance, thereby providing a correction factor that would account for any leakage or error in the experiment.

\section{CONCLUSIONS}

The catalytic reactivity of single salt catalysts used in gasification of coal is in the following order: $\mathrm{Li}_{2} \mathrm{CO}_{3}>\mathrm{Cs}_{2} \mathrm{CO}_{3}>\mathrm{CsNO}_{3}>\mathrm{KNO}_{3}>\mathrm{K}_{2} \mathrm{CO}_{3}>\mathrm{K}_{2} \mathrm{SO}_{4}>\mathrm{Na}_{2} \mathrm{CO}_{3}>\mathrm{CaSO}_{4}$. The catalytic activity increased by varying degrees with catalyst loading. The eutectic catalysts increased gasification rate. In general, the observed activity order was ternary $>$ binary > single salts. The $43.5 \% \mathrm{Li}_{2} \mathrm{CO}_{3}-31.5 \% \mathrm{Na}_{2} \mathrm{CO}_{3}-25 \% \mathrm{~K}_{2} \mathrm{CO}_{3}$ eutectic catalyst was the best among the ternary eutectics. Of the binary eutectics, the $29 \% \mathrm{Na}_{2} \mathrm{CO}_{3}-71 \% \mathrm{~K}_{2} \mathrm{CO}_{3}$ eutectic and the $2.3 \% \mathrm{~K}_{2} \mathrm{CO}_{3}-97.7 \% \mathrm{KNO}_{3}$ eutectic gave the best results. The methods of catalyst preparation and addition had significant effects on the catalytic activity and coal gasification. For soluble catalysts, the incipient wetness method gave more uniform catalyst distribution than that of physical mixing resulting in higher gasification rates for the incipient wetness samples. It was found that the eutectics are highly insoluble in aqueous medium and that catalysts added as eutectic salts to the coal gave better gasification rates than catalysts prepared by mixing individual salts in the eutectic ratio with the coal. The composition of the sample had significant effect on the surface charge property and gasification rate. The above results are especially important since the eutectic catalysts (with low melting points) yield significant gasification rates even at low temperatures. Application of such catalysts should, therefore, reduce the severity of gasification processes.

\section{FUTURE WORK}

The project team continues to meet every two months and significant progress has been made. Based on the studies at $\mathrm{CAU}$ and the discussion of the results at project group meetings, the activities of the $29 \% \mathrm{Na}_{2} \mathrm{CO}_{3}-71 \% \mathrm{~K}_{2} \mathrm{CO}_{3}$ and $2.3 \% \mathrm{KNO}_{3}-97.7 \% \mathrm{~K}_{2} \mathrm{CO}_{3}$ binary system and the $43.5 \% \mathrm{Li}_{2} \mathrm{CO}_{3}-31.5 \% \mathrm{Na}_{2} \mathrm{CO}_{3}-25 \% \mathrm{~K}_{2} \mathrm{CO}_{3}$ ternary system have been shown to give better gasification results. Future studies, specially with the bench scale fixed-bed gasification reactor at UTSI will concentrate on these catalyst systems. The effect of temperature, pressure and steam to carbon ratio will be studied to find optimum conditions for higher gasification and methanation reaction. Additional new eutectic salts will be studied at CAU to identify which eutectic catalyst gives the best results. Characterization of the coal, catalyst and char samples will be actively pursued at Georgia Tech in the next report period.

\section{REFERENCE}

(1) Levin, E. M., Robbins, C. R. and McMurdie, H. F. "Phase Diagrams for Ceramist", American Ceramic Society, Columbus, Ohio, 1964. 
Figure 1 Process Schematics for Runs 1 - 4

\section{Run 1}
Raw coal $\rightarrow$ Pyrolysis $\rightarrow$ Drying $\rightarrow$ Gasification $\uparrow$
Catalyst (M3)

Run2

Raw coal $\rightarrow$ Drying $\rightarrow$ Pyrolysis $\rightarrow$ Gasification Catalyst (M3)

\section{Run 3}

Raw coal $\rightarrow$ Drying $\rightarrow$ Pyrolysis $\rightarrow$ Gasification $\uparrow$

\section{Run 4}

Raw coal $\rightarrow$ Drying $\rightarrow$ Pyrolysis $\rightarrow$ Gasification Catalyst (M1) 

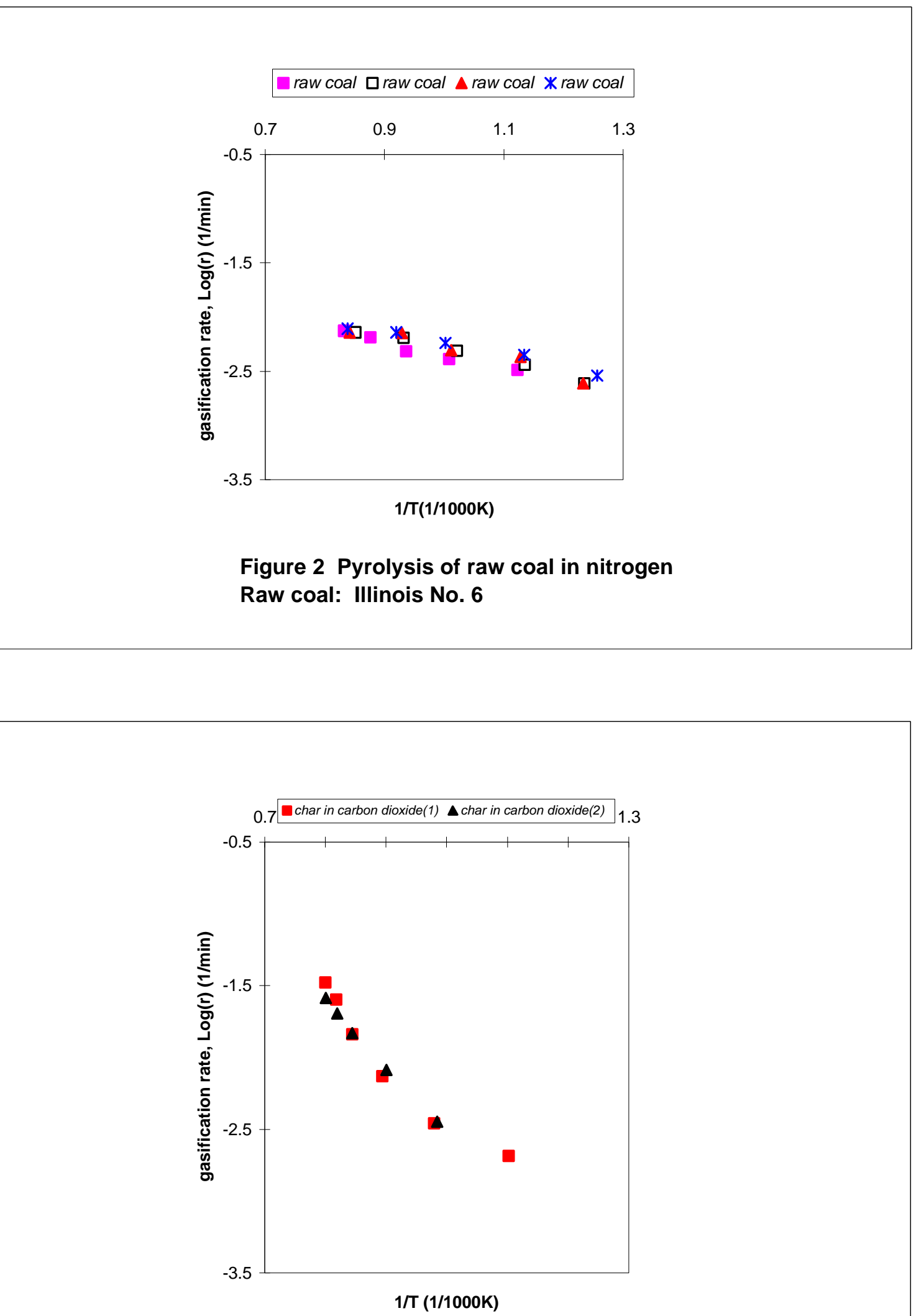

Figure 3 Gasification rate of char versus $1 / T$ in carbon dioxide 
Figure 4 G asification of coal catalyzed by single car bonate salt in $\mathrm{CO} 2$ M ethod: Physical mixing of coal with solid salt car bonate
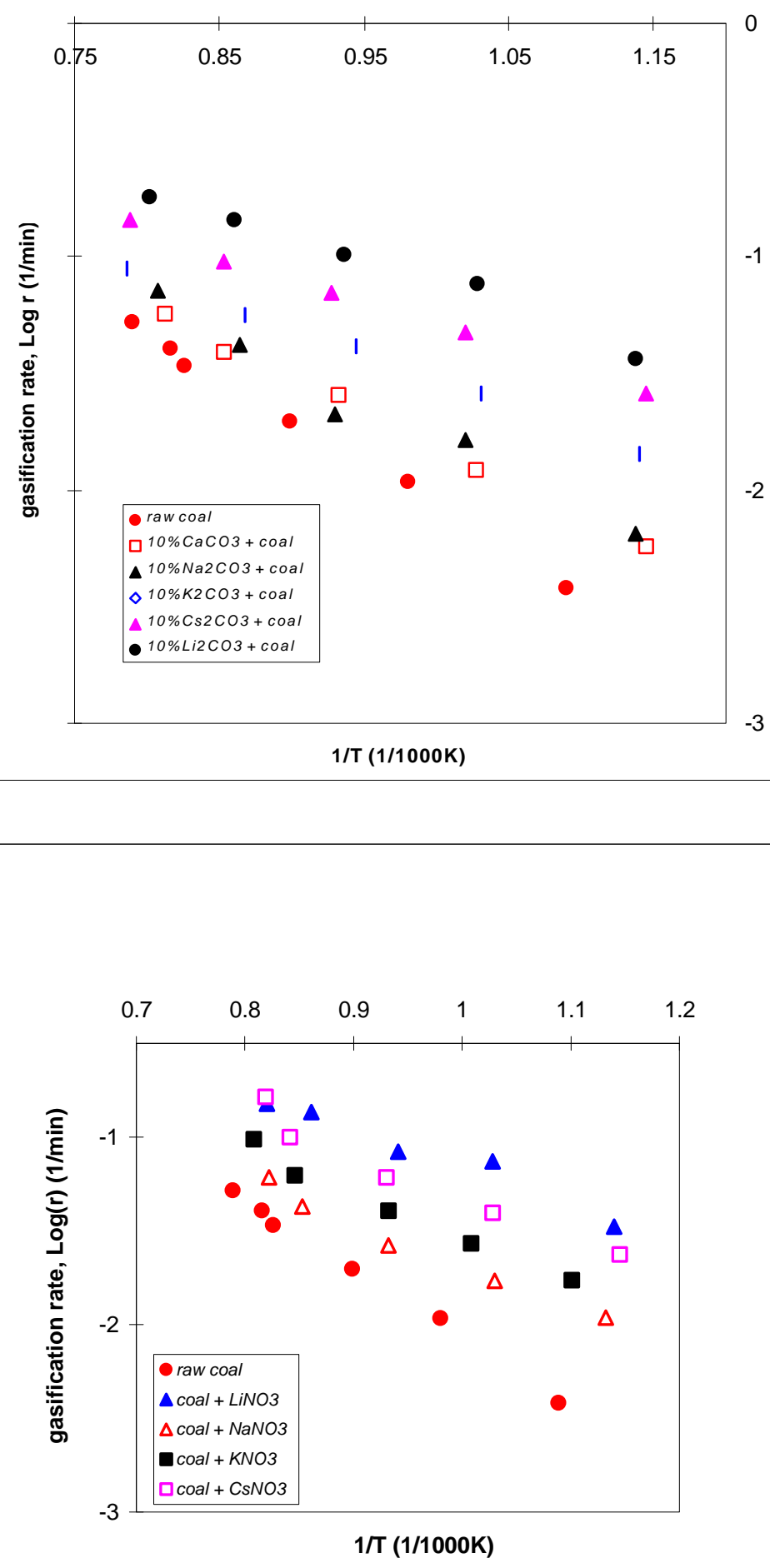

Figure 5 Gasification of coal catalyzed by single nitrate salt in $\mathrm{CO} 2$ Method: physical mixing of coal with solid nitrate salt 


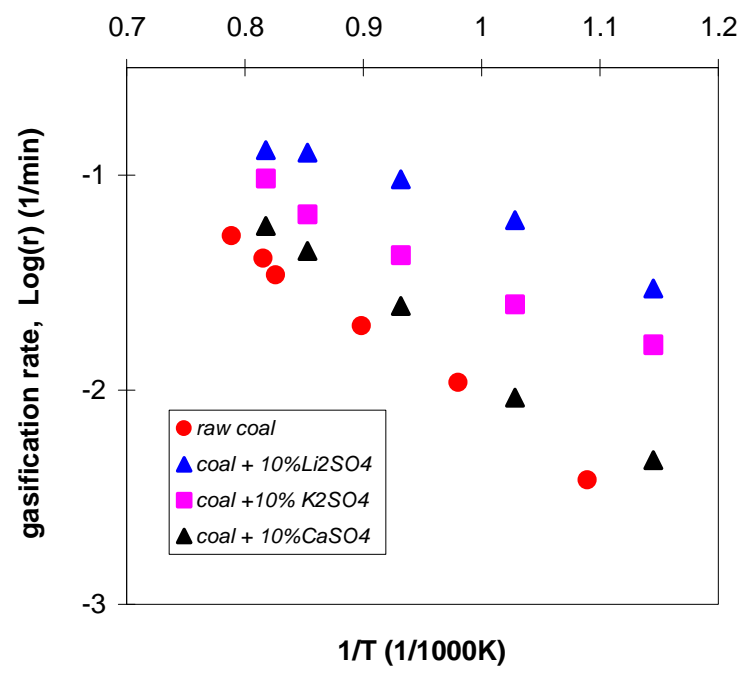

Figure 6 Gasification of coal catalyzed by single sulfate salt in $\mathrm{CO} 2$ Method: physical mixing of coal with sulfate salt

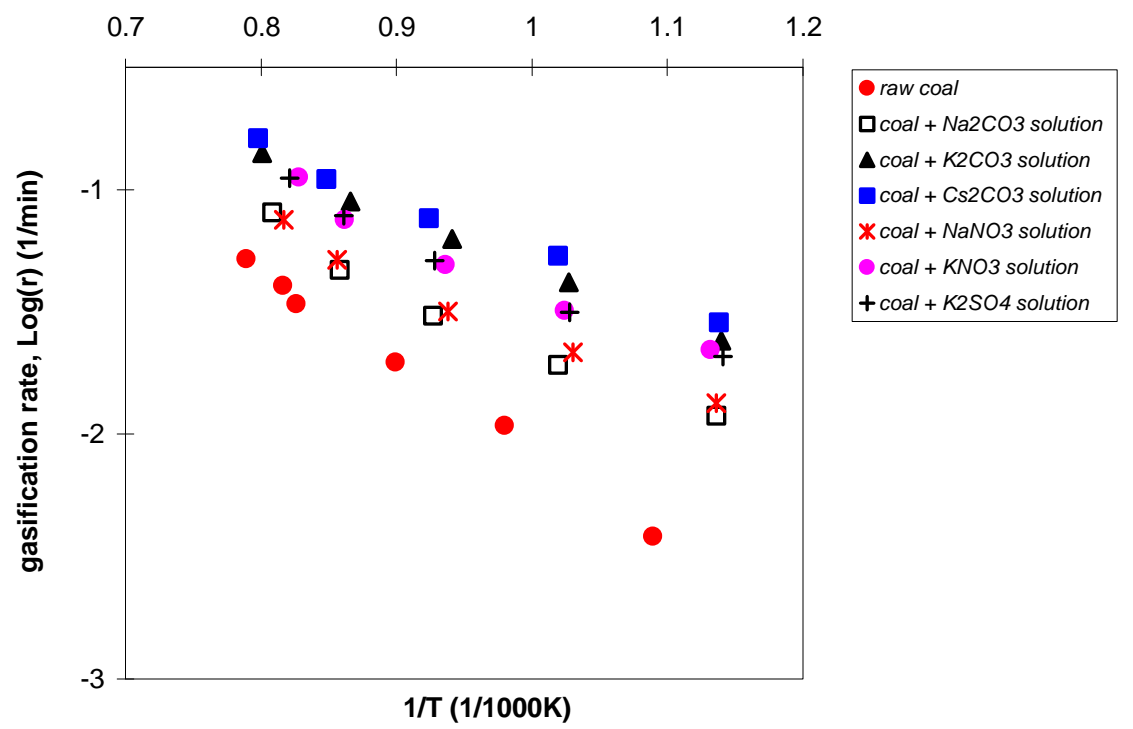

Figure 7 Gasification of coal catalyzed by single salt catalysts in $\mathrm{CO} 2$ Samples prepared by incipient wetness method 


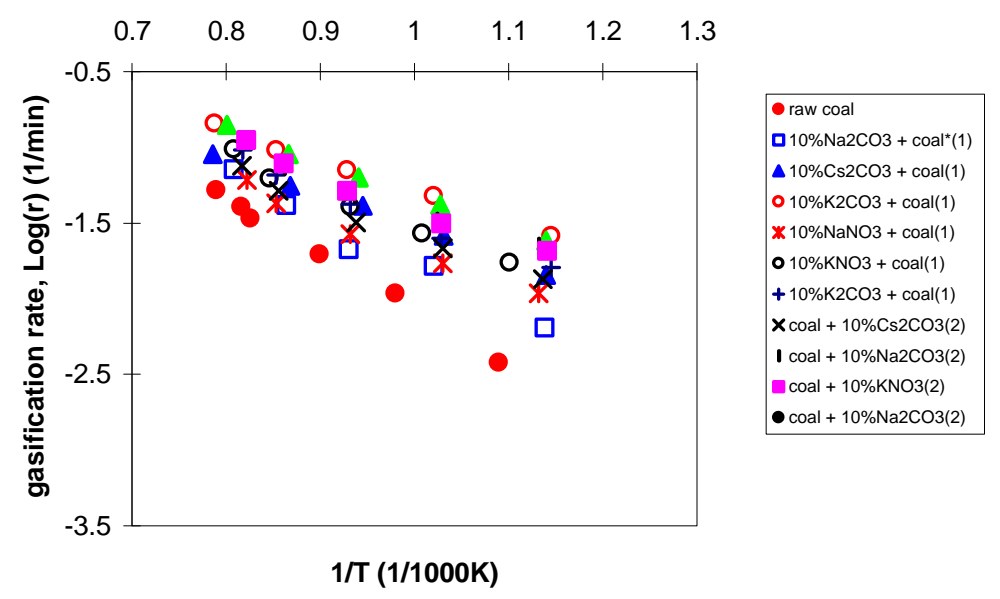

Figure 8 Gasification of coal catalyzed by single salt catalysts in $\mathrm{CO} 2$ Sample prepared by

1. physical mixing method; 2. incipient wetness method

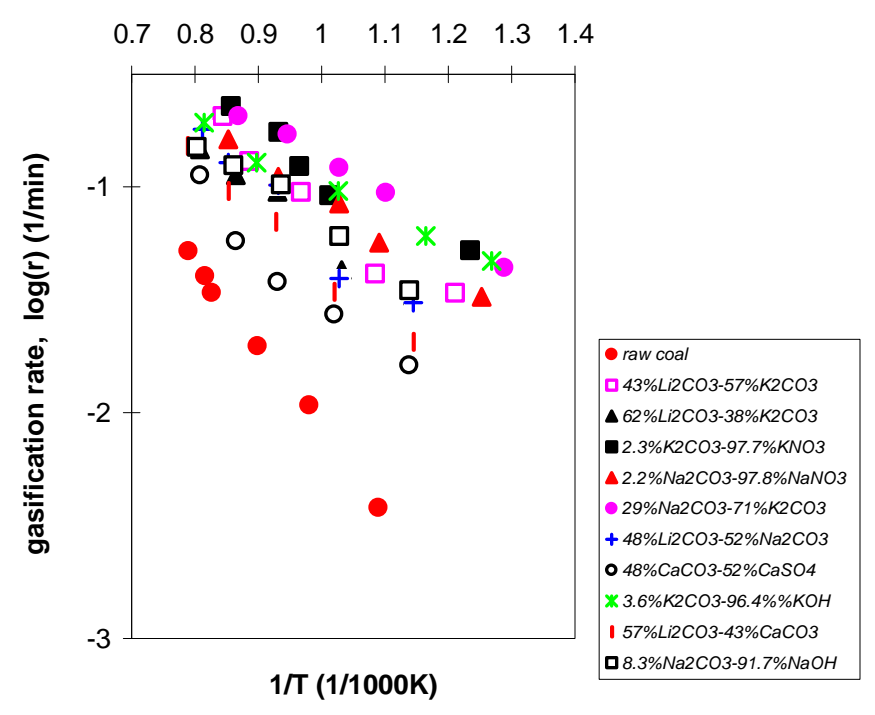

Figure 9 Gasification of coal catalyzed by binary salt mixtures in $\mathrm{CO} 2$ Method: physical mixing of coal with solid binary salt mixture 


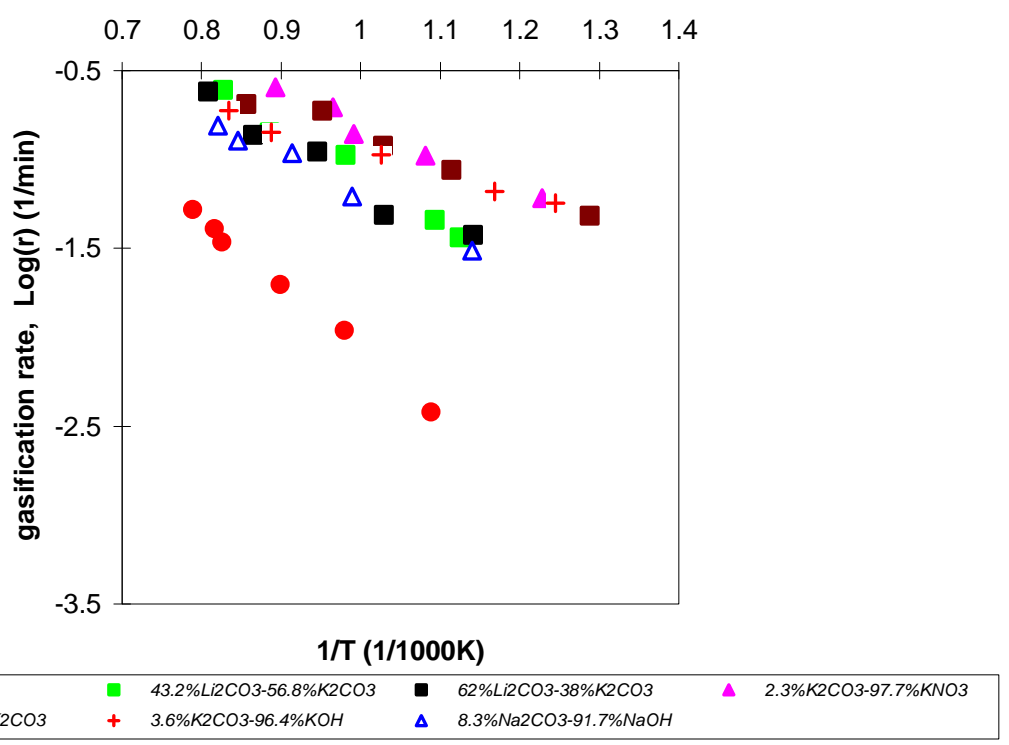

Figure 10 Gasification of coal catalyzed by binary eutectic catalysts method: physical mixing of coal with solid binary eutectic catalysts

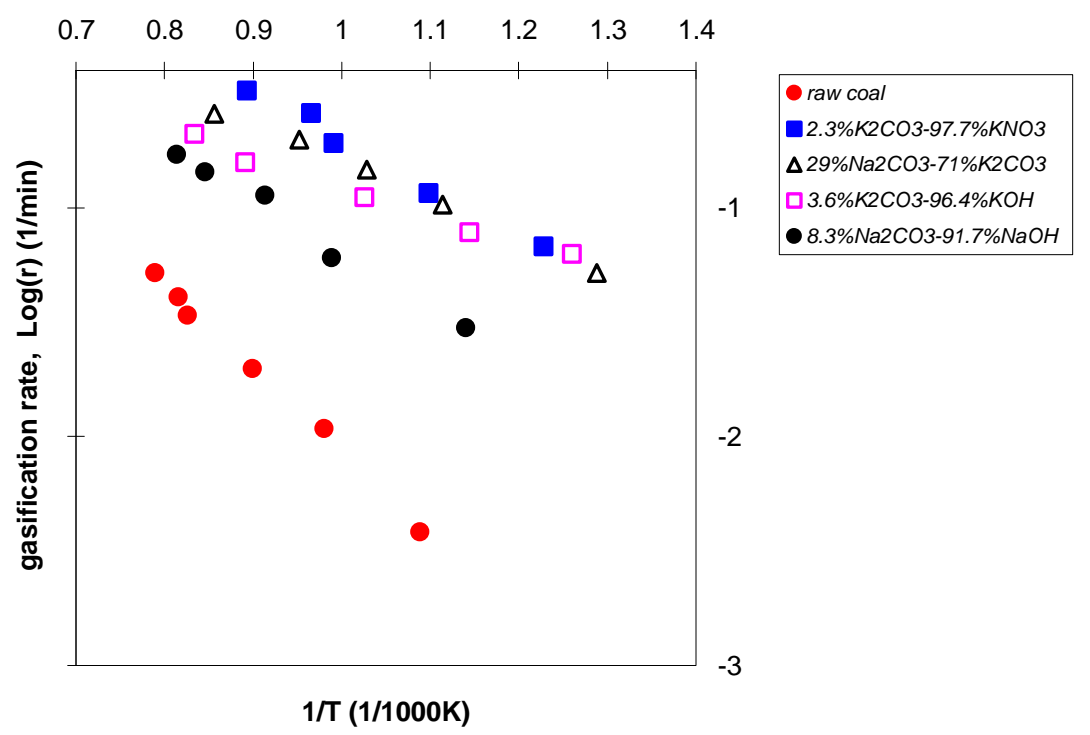

Figure 11 Gasification of coal catalyzed by binary salt mixture catalysts in $\mathrm{CO} 2$

Method: Incipient wetness method 


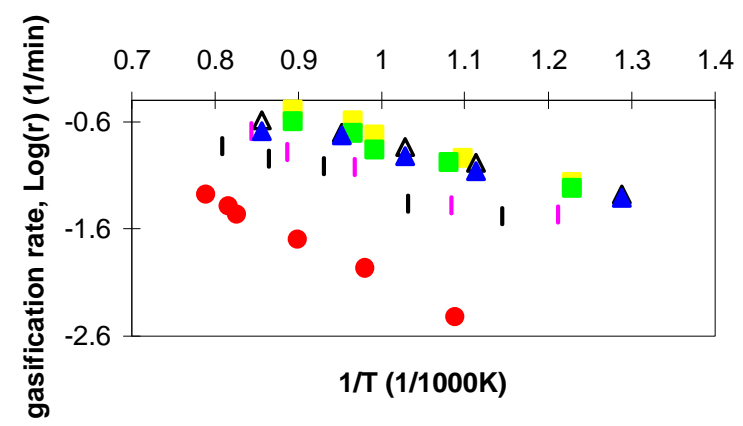

\begin{tabular}{|llll|}
\hline- raw coal & $2.3 \%$ K2CO3-97.7\%KNO3(*a) & $\Delta 29 \% N a 2 C O 3-71 \%$ K2CO3(a) & I 2.3\%K2CO3-97.7\%KNO3(b) \\
\hline I 29\% Na2CO3-71\%K2CO3(b) & $2.3 \%$ 2CO3-97.7\%KNO3(c) & $\Delta 29 \% N a 2 C O 3-71 \% K 2 C O 3(c)$ & \\
\hline
\end{tabular}

Figure 12: Gasification of coal catalyzed by binary catalyst prepared by different application methods

a:prepared by incipient wetness method; b:physical mixing coal with solid salt mixture; c:physical mixing solid eutectic mixture with coal.

Figure 13 Gasification of coal catalyzed by ternary catalyst in $\mathrm{CO} 2$ a-physical mixing of coal with solid eutectic catalyst; b-physical mixing of coal with solid salt mixture.

raw coal 25\%K2CO3-31.5\% Na2CO3-43.5\%Li2CO3(a) $\triangle 25 \%$ K2CO3-31.5\%Na2CO3-43.5\%Li2CO3(b)

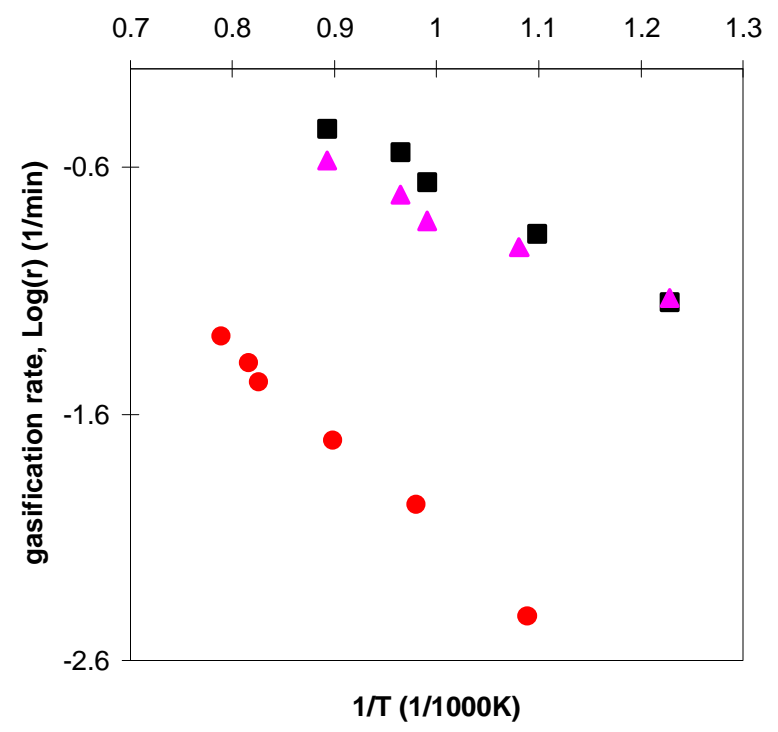




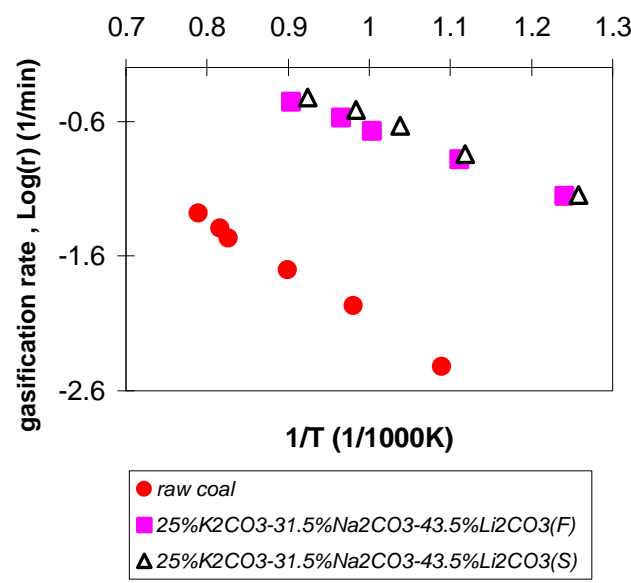

Figure 14 Gasification of coal catalyzed by ternary catalyst in $\mathrm{CO} 2$

F-gasified first time

S-gasified second time after cooling the first gasified sample to room temperature

Sample prepared by physical mixing of coal with ternary eutectic catalysts

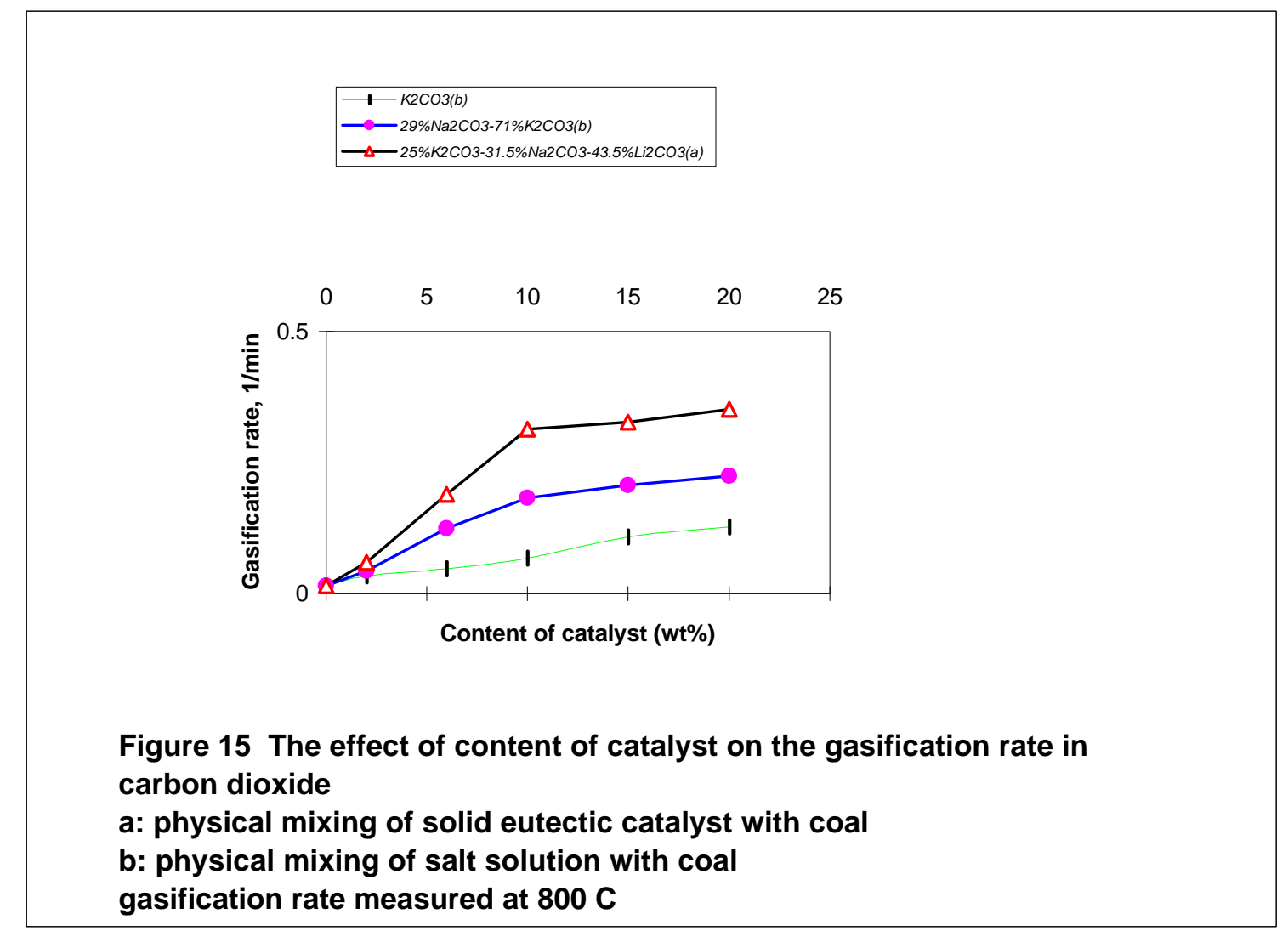




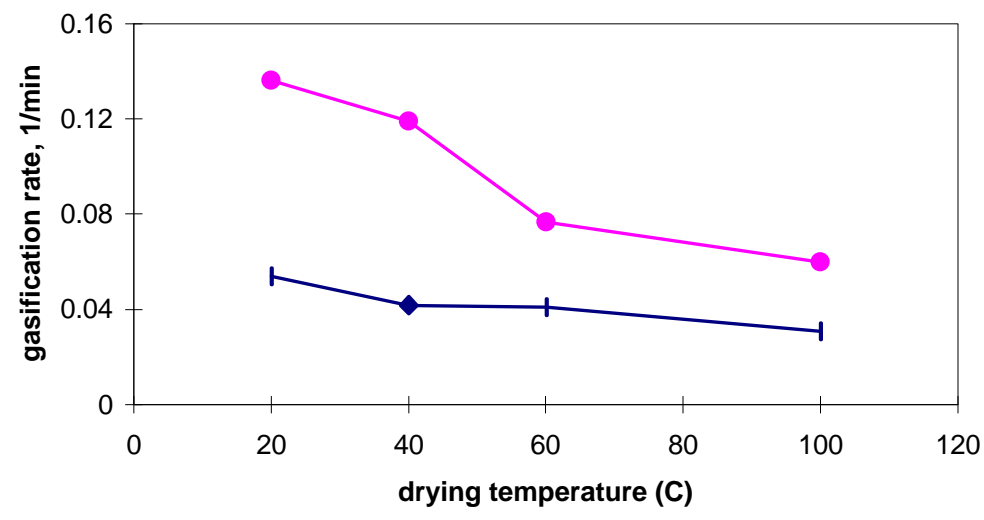

Figure 16 The effect of drying temperature on the gasification rate of coal in carbon dioxide after 72 hours samples prepared by incipient wetness method

Figure 17 The effect of drying time of the sample on the gasification of coal in carbon dioxide at room temperature Sampe prepared by incipient wetness method gasification rate measured at $800 \mathrm{C}$

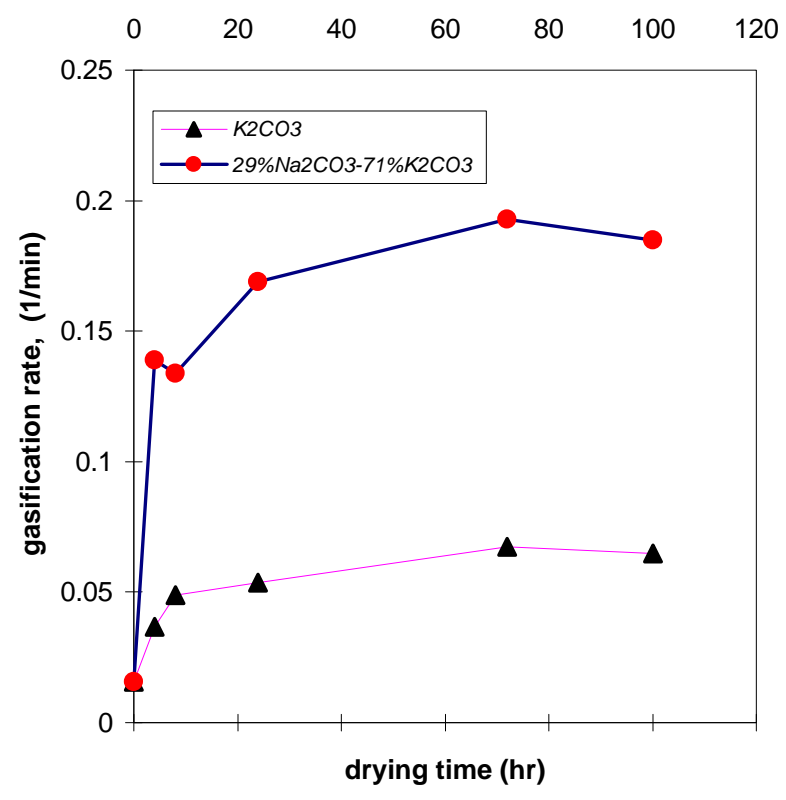




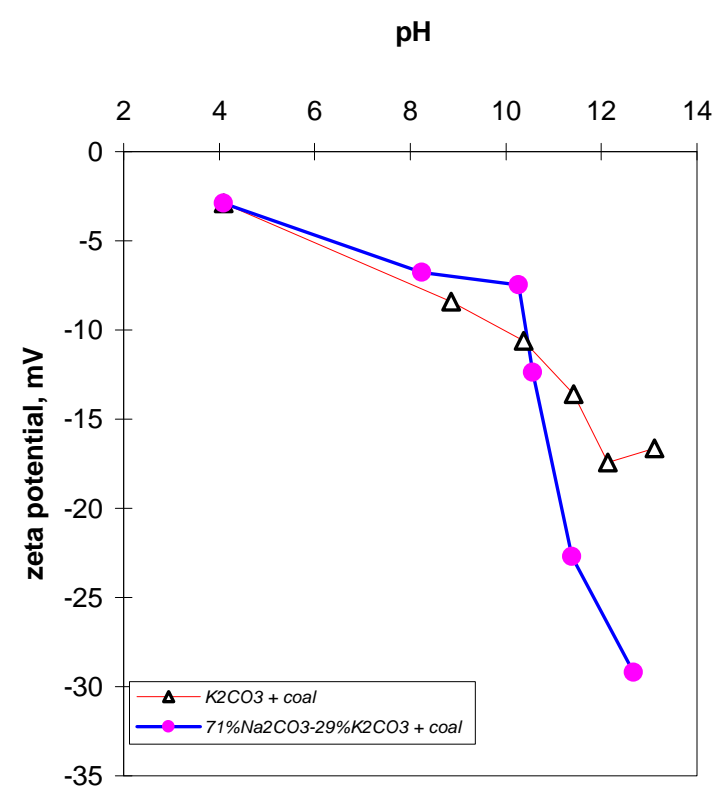

Figure 18 Zeta potential versus $\mathrm{pH}$ curve Samples prepared by incipient wetness method

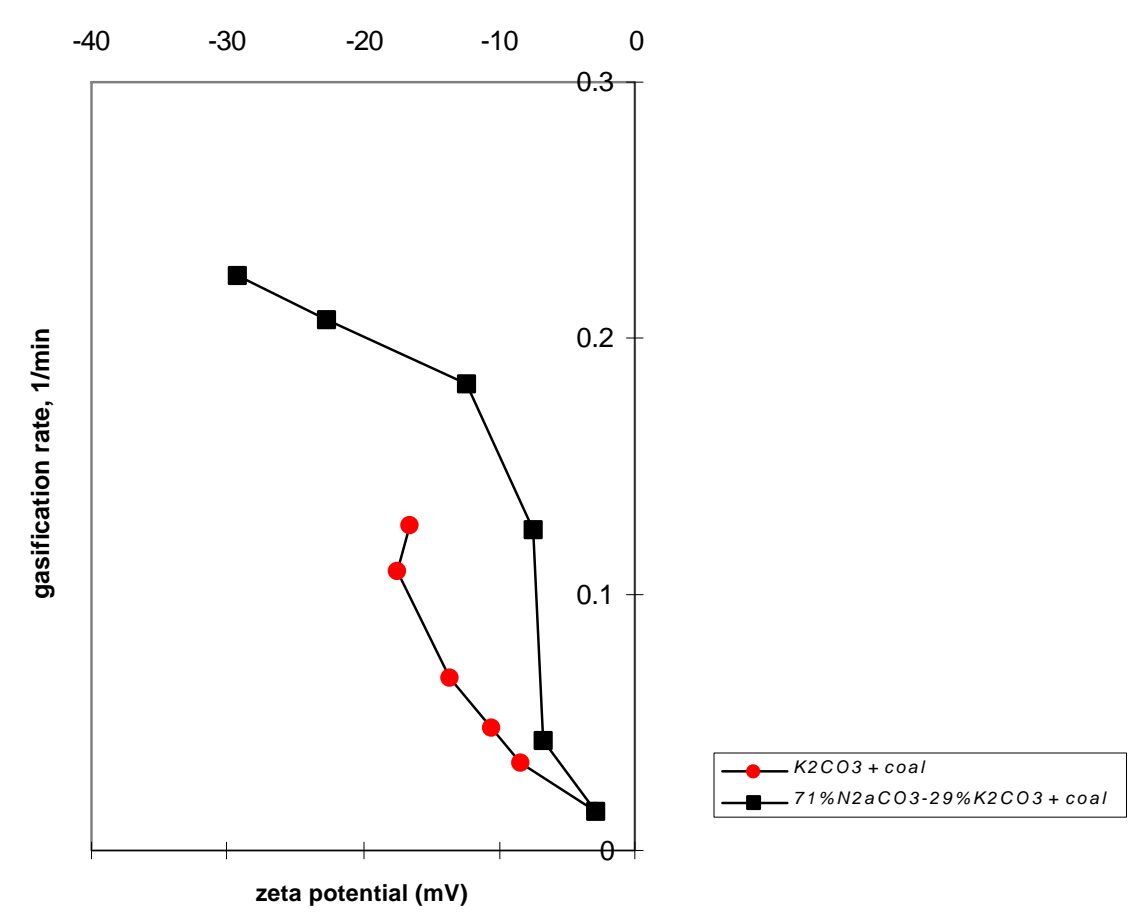

Figure 19 Zeta potential ver sus gasification rate Samples prepar ed by incipient wetness method 
Figure 20. Specific gasification rates vs Carbon conversion for Runs 1 - 4

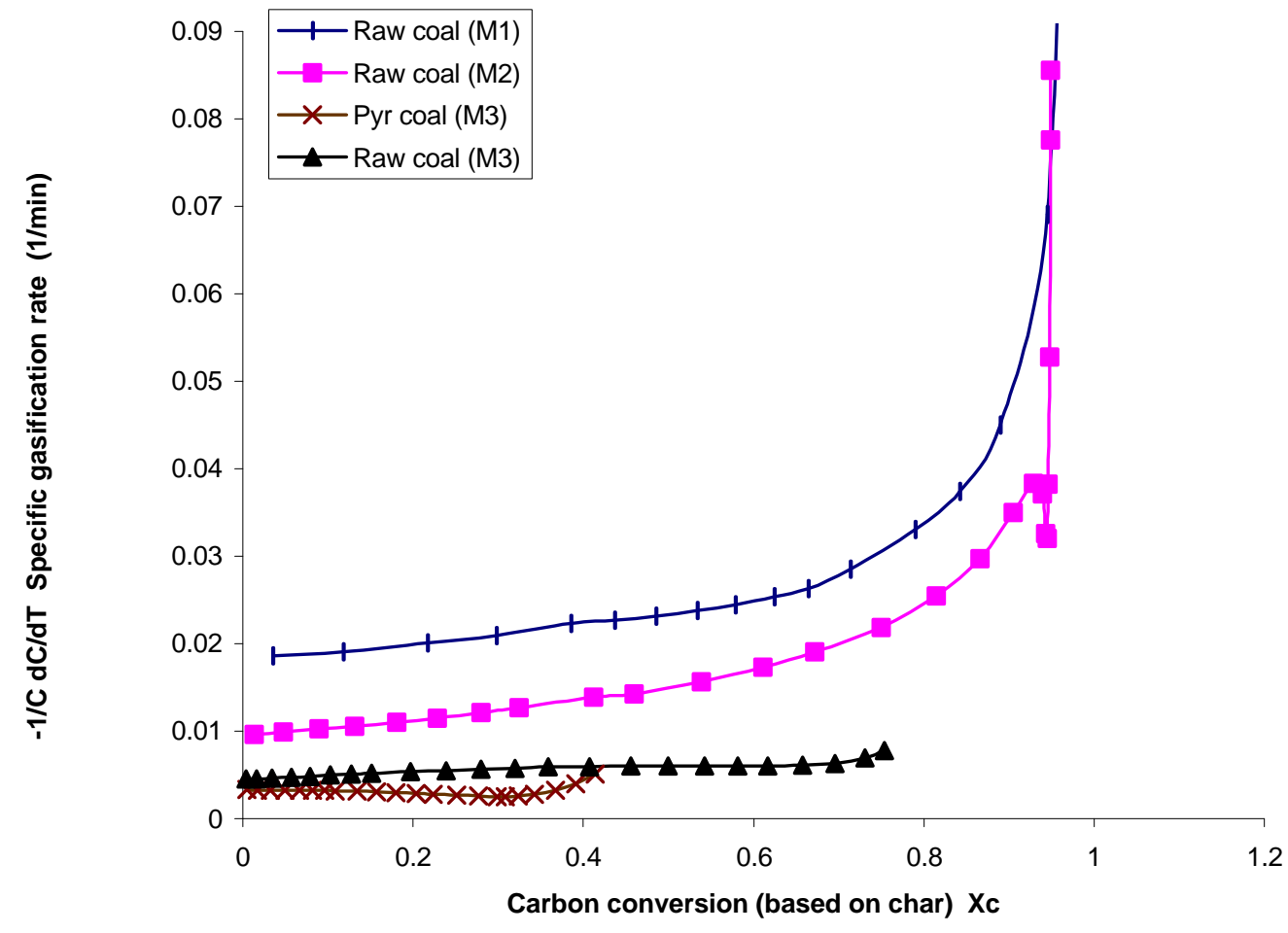




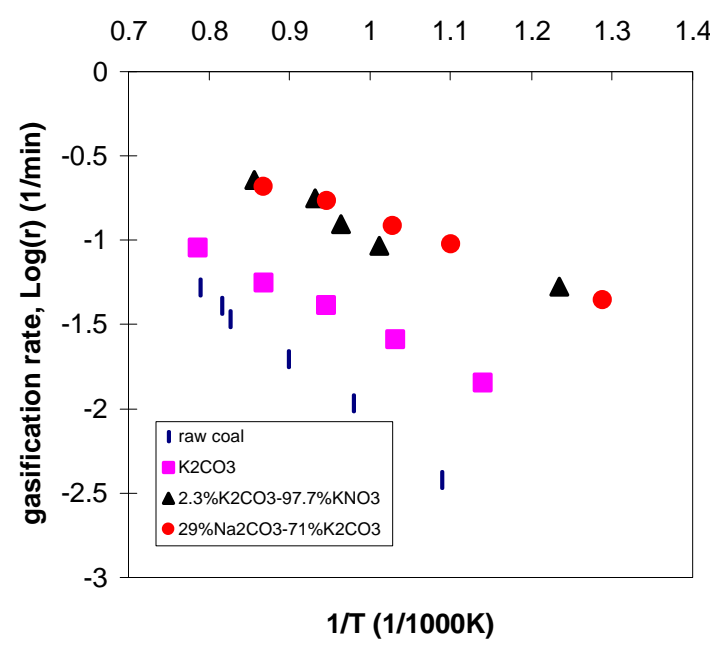

Figure 21 Gasification of coal catalyzed by salt catalysts in $\mathrm{CO} 2$ $M$ ethod: physical mixing of coal witl solid salt catalyst

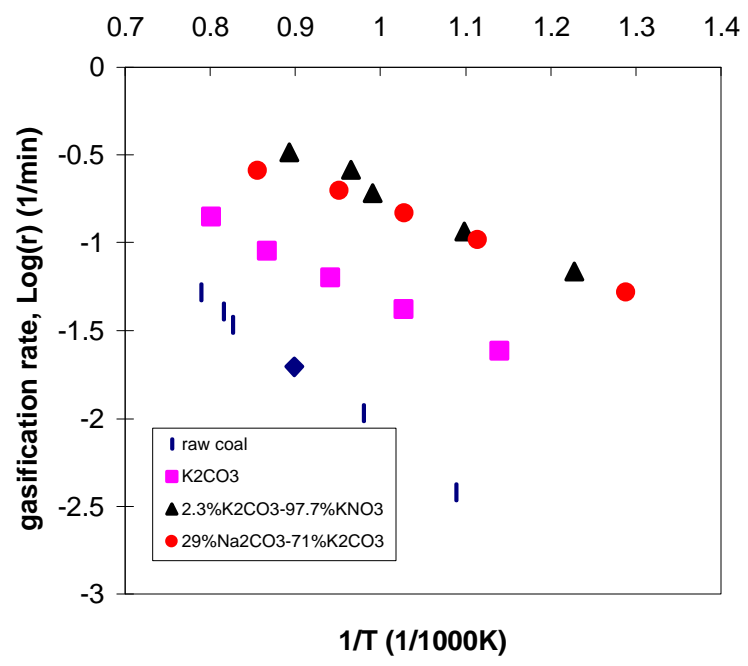

Figure 22 Gasification of coal catalyzed by salt catalysts in $\mathrm{CO} 2$ sample prepared by incipient method 